\title{
LEVELS OF As, Pb, Cd AND Fe IN SUSPENDED PARTICULATE MATTER (SPM) IN AMBIENT AIR OF ARTISAN WORKSHOPS IN BENIN CITY, NIGERIA
}

\author{
Okuo, J.M. and *Okolo, P.O. \\ Department of Chemistry, Faculty of Physical Sciences, University of Benin, Benin City, Nigeria. \\ *Correspondence author: okolopao@yahoo.com
}

\begin{abstract}
Suspended Particulate Matter (SPM) collected from three different artisans' workshops was analyzed for As, Cd, Pb and Fe by Atomic Absorption Spectrophotometry (AAS). The range of SPM concentrations for the three workshops was $583-20,166 \mu \mathrm{g} / \mathrm{m}^{3}$. The highest concentrations of these elements were observed in Motor Spray Painting (MSP),8528 $\pm 389 \mu \mathrm{g} / \mathrm{m}^{3}$ and Welding and Panelbeating (WDP) workshops, 11086.8 $\pm 10644 \mu \mathrm{g} / \mathrm{m}^{3}$. The calculated enrichment factor revealed Cd to be highly enriched in Battery Maintenance and Charging (BMC) and MSP. The enrichment factor of all the elements suggests that there was a significant contribution from anthropogenic sources. These values of SPM obtained violate both FEPA,1991 and WHO,1994 standards.
\end{abstract}

Keywords: suspended particulate matter, metals, workshops, city, Nigeria.

\section{INTRODUCTION}

In recent times increasing attention has been paid to the various elements present in the environment and the possible effects on human health. One of the most basic and most useful indicators for the degree of air pollution is the Suspended Particulate Matter (SPM) level. The greatest air pollutant in Nigerian environment is atmospheric dust (Akeredolu, 1989), so baseline studies of it have received a wider attention than the other types of air pollutants. Levels of SPM as high as $40,000 \mu \mathrm{g} / \mathrm{m}^{3}$ have been recorded in some industrial sites while up to $1033 \mu \mathrm{g} / \mathrm{m}^{3}$ were reported for ambient air (Asubiojo et al., 1993). Human health is commonly affected by damage done to the body organs and tissues as a result of absorption through respiration of Suspended Particulate Matter (SPM) which contains heavy metals and trace elements. Elemental constituents of aerosol present in biosphere have been identified as potential hazards to human beings. Some of them are insidious pollutants because of their non-biodegradable nature. In terms of adverse effects on human health, particulate matter is perhaps the most important air pollutant. Epidemiological studies have linked air pollution episodes to health problems and toxicological studies have been critically examined (Anderson et al., 1999). Because of the risks posed by elements in Suspended Particulate Matter to human health and the ecosystem, it is important to develop effective control measure for air particulate emission. However, an important step in air pollution control program is the identification of pollutants, the contributing source and the relative contribution of each sources. Several workers have measured trace elemental concentrations in air borne aerosols from some Nigerian cities (Ndiokwere, 1983; Asubiojo et al., 1992; Ogunsola et al., 1994 and Oluyemi et al., 1994). Elemental composition of SPM in ambient air of artisan workshops from any Nigerian city has scarcely been investigated. Recently there has been a tremendous increase in the number of small-scale industries in Benin City and its environs. These small-scale industries have their own characteristic pollutants emitted into the atmosphere. Some of these pollutants, particularly the SPM and their elemental constituents are known to be hazardous to human health (Akeredolu, 1989). It is therefore pertinent to investigate the activities of these small-scale industries in Benin City. This has necessitated the present study to ascertain the degree of contamination of air in Benin City by these small-scale industries.

\section{MATERIALS AND METHODS}

This study was conducted in Benin City, Edo State, Nigeria. Three types of small-scale industries were chosen for the study. They are Battery Maintenance and Charging (BMC), Motor Spray Painting (MSP) and Welding and Panel Beating (WDP).

Sampling of Suspended Particulate Matter (SPM)

Six sampling areas were selected for the study: Ugbowo, New Benin, Sakponba Road, $3^{\text {rd }}$ East Circular, Ikpoba Hill/Agbor Road, Sapele Road and Ekenhuan Road. The sampling areas were chosen, such that the activities of these three types of smallscale industries are prevalent. Five workshops each were selected from BMC, MSP and WDP. A total of 90 workshops from the three different small-scale industries were used for the study. It is pertinent to note that wastes from these industries were disposed of indiscriminately in the premises of the workshops sampled. Some of these shops particularly the BMC were located in residential houses while others were in open spaces in between residential houses. All samples were collected at a height of $7 \mathrm{~m}$ above the ground surface and the apparatus was sheltered from any direct rain(Mueller and Smith, 1991) . 
SPM samples were collected using SKC sidekick sampling pump 224-50. This was done by filtration on whatman membrane filters of $25 \mathrm{~mm}$ with a pore size of $3.0 \mu \mathrm{m}$. This is very good for elemental analysis because of low back ground levels of inorganic materials (Mueller and Smith, 1991). Sampling was done during working hours and Saturdays from $8.00 \mathrm{am}$ to $6.00 \mathrm{pm}$ i.e. $10 \mathrm{hrs}$ (Ogunsola et al, 1994 and UNEP/WHO, 1994b). An IOM sampling head, which housed the cassette assembly was fitted to a sidekick pump by a Teflon tube. The whole assemblage, referred to as high volume Air Sampler, was obtained from SKC limited, Bland ford forum, U.K. The sampling operates at a nominal flow rate of 0 $10.00 \mathrm{Lmin}^{-1}$. The flow rate was determined by a flow meter (rotameter). A total of $1500 \mathrm{~L} / 10 \mathrm{hr}$ air was sampled for each sampling day. For each sampling, the filter and cassette were humidity-conditioned (equilibrated) in a charged desicator for $24 \mathrm{hrs}$ and weighed before and after sampling. The amount of SPM collected per volume of air sampled was the difference between the two weights. The loaded filters were stored in polyethene bags and taken to the laboratory for sample preparation and elemental analysis by Atomic Absorption Spectroscopy (AAS) (Ogunsola et al, 1994 and UNEP/WHO, 1994b).

The Suspended Particulate Matter (SPM) was calculated by the following formular: $\quad$ SPM = Wp/Vair,

where SPM $=$ Total Suspended Particulate Matter $\left(\mu \mathrm{g} / \mathrm{m}^{3}\right)$,

$\mathrm{Wp}=\mathrm{W}_{1}-\mathrm{W}_{0}=$ Weight of particulate matter, where $W_{1}$ is the weight of loaded filter and $W_{0}$ is the weight of unloaded filter.

Vair = Fr $\times$ St = volume of air sampled; where $\mathrm{Fr}$ is the flow rate and St the sampling time.

Samples Preparation and Measurement For SPM For AAS analysis, the loaded filter paper was treated with $7.5 \mathrm{~cm}^{3}$ of boiling concentrated $65 \% \mathrm{HNO}_{3}$ inside a Teflon beaker. Five centimeter cube of $70 \% \mathrm{HClO}_{4}$ was added, then heating continued at $120^{\circ} \mathrm{C}$ until the solution became clear. The excess acid was boiled off and the dried material re-dissolved in $2.0 \mathrm{~cm}^{3}$ of concentrated $\mathrm{HNO}_{3}$ by gentle heating. The solution was cooled and diluted to $50.0 \mathrm{~cm}^{3}$ in a volumetric flask. This was then analyzed using Buck Scientific model-200A/213 AA instrument. AAS measurements were carried out using a Perkin - Elmer Atomic Absorption Spectrophotometer (Buck Scientific Model $200 \mathrm{~A} / 213$ ) with double beam back ground(Ogunsola et al, 1994 and UNEP/WHO, 1994b Ogunsola et al, 1994 and UNEP/WHO, 1994b).

\section{Statistical Analysis}

Range, mean concentrations, enrichment factors, and variance were calculated for the SPM and heavy metals( $\mathrm{As}, \mathrm{Pb}, \mathrm{Cd}$ and $\mathrm{Fe}$ ) in different workshops. ANOVA values, such as Fischer(F), and Probability(P) values were performed to show the level of significance of the relationship between the different artisans' workshops in terms of SPM and heavy metal concentrations(Agatemor and Okolo, 2007). The results of this study are presented in Tables 1-3.

\section{RESULTS AND DISCUSSION}

Tables 1-3 presents the range, mean concentrations, enrichment factors, variance and ANOVA values for the SPM and heavy metals in different workshops.

The average concentrations of SPM measured for the three types of workshops are 5280.53, 8528 and $11086 \mathrm{\mu g} / \mathrm{m}^{3}$ for BMC, MSP and WDP respectively. These are 9, 34 and 43 -folds the value of $250 \mu \mathrm{g} / \mathrm{m}^{3}$ annual average stipulated by the national air quality regulating agency (FEPA, 1991). These values also exceeded the UNEP/WHO(1994) standard of $40 \mu \mathrm{g} / \mathrm{m}^{3}$. In comparison to similar studies conducted in Khartoum (Sudan) and Ife (Nigeria) where similar work were done by Eltayeb et al(1993) and Ikamaise and Obioh (2001) respectively, the values obtained in this work were about 12 and 97 times that of Sudan and Ife, respectively. The reasons for our high values, particularly that for WDP, may be due to air borne emissions from these small scale industries. It may also be attributed to meteorological factors such as frequency in the variation of rainfall, wind direction and turbulence (Pastuska et al, 1993).

The SPM collected at the WDP workshops contained the highest level of all the elements determined. Some of the metal parts are alloyed. Cutting and welding of metals, indiscriminate disposal of metal parts, wastes from electric and oxy-acetylene welding might contribute to the levels of these metals observed. Other factors which will certainly contribute to the levels of the metals in the workshops are solid and liquid wastes, disposal of used batteries from BMC, aerosol paints and preliminary preparation of vehicle for painting such as scrapping of old paint in MSP workshops. Enrichment wastes from electric and oxy-acetylene welding might contribute to the levels of these metals observed. Enrichment factor for all the elements was also computed. All the elements have enrichment factor greater than 4 except Fe that was used as a normalizing species. lead was highly enriched in BMC and MSP while Cd was also highly enriched in MSP and WDP. Arsenic (As) was moderately enriched in the three workshops. This is obviously not from natural sources. Anthropogenic sources such as automobile exhausts, road dusts resuspension and other commercial activities also contribute to the observed levels.

Table 1: Range, mean and ANOVA levels of TSPM $\left(\mu \mathrm{g} / \mathrm{m}^{3}\right)$ at artisans' workshops in Benin City.

\begin{tabular}{lllllll}
\hline Artisans & Range & Mean & Variance & F(Anova) & P-value & F-crit \\
\hline BMC & $583-14083$ & $5280.53 \pm 5167$ & 26698305 & & & \\
MSP & $1750-15750$ & $8528 \pm 389.37$ & 32014126 & 4.858 & 0.014 & 3.285 \\
WDP & $6666.67-20,166.67$ & $11086.8 \pm 10644$ & 23121639 & & & \\
\hline
\end{tabular}


Table 2: Mean Levels of $\mathrm{As}, \mathrm{Cd}, \mathrm{Pb}$, and $\mathrm{Fe}\left(\mu \mathrm{g} / \mathrm{m}^{3}\right)$ at different artisans' workshops in Benin City.

\begin{tabular}{llllllll}
\hline $\begin{array}{l}\text { Artisans/F(Anova), P and } \\
\text { F crit. }\end{array}$ & As & Cd & Pb & Fe & F & P & Fcrit \\
\hline BMC & & & & & Anova & value & \\
MSP & $1.407 \pm 1.834$ & $0.030 \pm 0.048$ & $1.210 \pm 0.837$ & $2.456 \pm 1.340$ & 4.709 & 0.031 & 3.885 \\
WDP & $1.612 \pm 0.886$ & $1.217 \pm 0.870$ & $2.419 \pm 0.533$ & $3.689 \pm 0.443$ & 3.194 & 0.077 & 3.885 \\
& $3.280 \pm 1.216$ & $0.771 \pm 0.514$ & $2.024 \pm 0.022$ & $5.819 \pm 2.144$ & 10.106 & 0.005 & 4.256 \\
\hline
\end{tabular}

Table 3: Elemental concentrations in Typical Crustal Rock and the calculated Enrichment Factor at different artisans' workshops in Benin City.

\begin{tabular}{lllll} 
Elements & Typical crustal rock & \multicolumn{3}{c}{ Enrichment Factor } \\
\cline { 3 - 5 } & & BMC & MSP & WDP \\
$\mathrm{As}$ & 40 & 40.102 & 45.945 & 93.485 \\
$\mathrm{Cd}$ & 2 & 17.101 & 693.730 & 439.495 \\
$\mathrm{~Pb}$ & $10-300$ & 136.863 & 231.314 & 49.709 \\
$\mathrm{Fe}$ & 1 & 1 & 1 & 1 \\
\hline
\end{tabular}

\section{CONCLUSION}

The values of SPM obtained from artisans' workshops in Benin City violated both FEPA and WHO standards. Similarly, the high Enrichment Factor of the hazardous

\section{REFERENCES}

Akeredolu, F.A. (1989). Atmospheric environmental problems in Negeria - an overview. Atmospheric Environment, 23 :783-972.

Anderson, K.R; Avole, L; Edward, S.A Shamoo, D.A. Peng, R.C; Linn, W.S. Hackney, J.D. (1992) Controlled Exposure of Volunteers to Repairable Carbon and Waste Management Association 770-776.

Anderson, H. R. (1999). Health effects of air pollution episodes. In: Holdgate, S.T., Samet, J.M., Koren, A.S., Maynard, R.L. eds. Air Pollution Health. Academic Press London. Pp. 461-481.

Asubiojo, I.O.; Obioh, I.B; Ohiyemi, A.E; Ohwole, A.F Spyrou, A.S; Faroogi, W. and Akanle, O.A. (1993), Elemental characterization of airborne particulates at two Nigerian Locations during the harmattan. J. Radioanal, Nucl. Chem. Vol. 167(2): 283-293.

Agatemor, C. and Okolo, P.O.(2007). University of Benin water supply system: microbiological and physic-chemical assessments. Environmentalist, 27: 227-239.

Eltayeb, M.H.J.; Xhoffer, C.G.; Vanesspen, P.J.; Van Grieke, R.E.; Meanhant, W.(1993). Source and composition of aerosol from Kharton, Sudan. Atmospheric Environment, Part B. 27: 67-76.

FEPA(1991). Federal Environmental Protection Agency(Nigeria). National Interim Guidelines and Standards for Industrial Effluents, Gaseous Emissions and Hazardous Wastes in Nigeria. Abuja. Government Press, $p p$ 1-42.

Ikamaise, N.C., Obioh, I.B,(2001). Total suspended particulates in the Ambient Air of Welding workshops in Ile-Ife, Nigeria. Global Journal of Pure and Applied Sciences 4, 743-748. elements such as $\mathrm{Pb}$ and As call for urgent attention on the quantity of SPM exhausted into the atmosphere by some of the local industries in the city.

Mueller, W; and Smith D.L. (1991) Compilation of EPA'S sampling Analysis Methods, N.H. Keith Ed. Chelsea, M.I; Lewis Publisher

Ndiokwere, C.L. (1983) "A study of heavy Metal Pollution from Motor Vehicle Emission and Crops in Nigeria" Environmental Pollution series $\mathrm{B} 7$ : $35-42$.

Ogunsola, J.O.; Oluwole, A.F.; Obioh, I.B.; Akeredolu, F.A.; Asubiojo, I.O.; Akanle O.A.; and Spyrou, N.M. (1994) Analysis of Suspended Air Particulate along some motor high ways in Nigeria by PIXE and EDXRF; Nuclear Instrumentation and method in Physics Reasearch b. 79: 404-407.

Oluyemi, E.A; Asubiojo, I.O.; Oluwole, A.E. and Tousaint J.N. (1994) "Elemental concentrations and source identification of Air Particulate Matter at a Nigeria site. A preliminary study, Nuclear Analytical Methods in Atmospheric Pollution studies, Journal of Radio analytical and Nuclear Chemistry, Articles. 179, (2):187-194.

Pastuszka, J.; Hlawiczka, S. and Willeke, K. (1993). Particulate Pollution Levels in Katawice. A highly Industrialized Polish City. Atmospheric Environment 27B (1): 59-65.

UNEP/WHO (1994b) GEMS/AIR. Methodology Review Vol. 3, Measure of Suspended Particulate Matter in Ambient Air. WHO/EOS/94.3, UNEP/GEMS/94, A. 4, UNEP, Nairobi. 